\title{
Jakub Rataj, Gilberto Agostinho: Digitální technologie $v$ hudební tvorbě pro akustické nástroje, Praha, Nakladatelství AMU, 2016, 140 stran, ISBN 978-80-7331-419-4.
}

\section{Jan Borek}

Již název publikace - Digitální technologie v budebni tvorbè pro akustické nástroje - dosti velkoryse nastavuje představu potenciálně velmi širokého výkladu o digitálních technologiích $\mathrm{v}$ mnoha odvětvích hudební tvorby. $\mathrm{V}$ prvé radě však nejde o syntetickou práci zachycující celek činností, do nichž technologie vstupují. Ve dvou obsažených kapitolách čtenář dostává spiše úvod do konkrétnějších možností jejich aplikace a přiměřeně detailní př́padové studie. Pủvodně jde o akademické texty, přesněji kvalifikační práce obhájené na katedře skladby HAMU. Stylově se prístup $k$ hudbě, s níž príspěvky obou autorů operují, pohybuje spíše na úsečce seriáln - aleatorická. Obě skladatelské metody tu vstupují do vzájemného dialogu a ve výsledku vedle sebe fungují až symbioticky. Př́spěvek Jakuba Rataje hovoří o definici rozličných údajů a nastavení aparátu, s jehož pomocí pak tanečník volněji operuje - pohybem vlastního těla. Podobně to platí především o tzv. generativních partiturách, o nichž se zmiňuje Gilberto Agostinho. V nich se doposud jasná distinkce kontroly vstupních dat i ponechání prostoru k náhodě prakticky ztrácí.

Jak uvádí Michal Rataj v předmluvě, přes doposud vnímanou exkluzivitu elektronické hudby žádný z textů se svým hudebním obsahem rozhodně neoperuje z pozice exkluzivity. Autoři tedy prijímají integraci digitálních technologií do v̌sech stránek ( $v$ tomto př́ípadě) hudební produkce, tvorby, interpretace a operují s ním jako s rovnocenným nástrojem $\mathrm{k}$ dosažení daného výsledku.

Ratajova diplomová práce Převod pohybu lidského téla na zvuk pomocí senzorù z roku 2015 nejprve načrtává půlstoletí vývoje interaktivních systémů přenášejících taneční pohyb na hudbu. Představuje a kategorizuje pohybové senzory, důležitější je ale otevření ne zcela intuitivního problému charakteru tanečníka jako př́mého hudebního performera $\mathrm{v}$ reálném čase. Tuto výzvu řeší vlastním experimentem ve formě elektroakustické skladby s živou taneční složkou: Umèní manipulace (2014). Druhá polovina Ratajova textu detailním, avšak stále 
koncizním způsobem popisuje genezi tohoto díla, počínaje předchůdnou přípravou hudebního materiálu - partitury i samplů (které pak spadají do kompetence tanečníka) - a technického řešení taneční roviny. Jak sám zjištuje, ne zcela očividný rozsah možností využití tanečníka, včetně výběru adekvátního vybavení, musí být také upřesněn až v průběhu tvorby díla. Ladění citlivosti senzorů na míru konkrétnímu jednotlivci tedy ukazuje v podobném světle jako běžné zkoušky tradičních instrumentalistů.

Agostinhova bakalářská práce Generováni instrumentální hudby pomocí algoritmických postupů (2014) se zpočátku ohlíží spíše do minulosti. Ve stručném úvodu zmiňuje hlavní figury poválečné hudby - Pierra Bouleze, Iannise Xenakise či Johna Cage - a jejich odlišné př́istupy ke kompozici. Jak je však záhy možné zjistit, text postihuje „algoritmickou linii“ vývoje hudby od druhé poloviny 20. století až do př́tomné doby včetně výhledu do budoucna.

K otázce aplikace algoritmů v hudební tvorbě přistupuje $z$ několika hledisek. Po definici tř́ hlavních postupů, tedy programování dle daných pravidel, stochasticky či za pomoci umělé inteligence, uvádí několik ukázkových př́ípadů. Nechybí ani doslova open-source přiznání kompletního zdrojového kódu počítačového programu potřebného $\mathrm{k}$ vytvoření popsaných skladeb včetně možnosti volného stažení všech potřebných souborů. Oproti názvu knihy je třeba zmínit, že žádná z popsaných skladeb vposled nepotřebuje ke své tvorbě ani úspěšné interpretaci aplikaci digitálních technologií. Kromě toho i samotný termín algoritmus máme bytostně spjat s mechanickými či elektronickými prŕstroji. Autor ovšem připomíná, že př́sně vzato spadá veškerá hudební tvorba pod určitý proces či soubor pravidel. Představené Rileyho či Reichovy minimalistické kompozice pak nabízí jistý kotvící bod s přehledným kompozičním postupem - kupř. postupným posunováním jednotlivých partů v Clapping Music.

Praktické ukázky však pouze doplňují a vhodně ilustrují teoretický základ. Agostinho ve své práci jmenuje algoritmické prrístupy od dobře známých pravidel Fuxova kontrapunktu 1:1 přes stochastické programování blíže operující s elementem náhody po pokročilé systémy umělé inteligence, umožňující zatím nejvyšší míru tvưrčí autonomie stroje při procesu, jež bychom mohli označit za legitimní hudební skladbu. Na závěr již ona zmíněná role digitálních technologií narůstá - až po pojem tzv. generativních partitur. V nich nalézáme zcela odlišný přístup k hudebnímu dílu - či jeho uchopení jakožto (pokud laskavý čtenář dovolí jazykovou hřičcku poukazující na hned několik významů najednou) díla in|forma|tického. Tedy díla př́ísně vzato nedokončeného. Zpočátku ve formě pouhé digitální informace, jejíž výsledná podoba závisí na konkrétním rozvinutí skrze algoritmus. $V$ tomto paradigmatickém posunu nalézáme další spojení protikladů: disponování dílem se stává univerzálním (ve formě výchozí informace) 
a zároveň unikátním (pokud hovoříme o jedinečném, pokaždé odlišném výsledku). Ona hudba je svým způsobem skryta již v daném prostoru řešení, vždy kolabujíc do mírně odlišné aktuální, konkrétní slyšitelné formy, na základě vstupních proměnných. Je škoda, že nejhlubší a nejaktuálnější esteticko-teoretická úvaha o uměleckých důsledcích generativních partitur dostává až př́liš skromné místo na samém závěru knihy.

Otevřenost, s níž publikace operuje, je vítaná. Nejen v době všudypřítomného průmyslového tajemství, ale především v době, kdy je i u předních soudobých umělců vydání partitury naprostou raritou, zde dostáváme přes 30 stran kompletních zdrojových kódů i důkladný vhled do Ratajova tvůrčího procesu. Vzhledem $\mathrm{k}$ charakteru př́spěvků jakožto akademických prací je přirozené, že v sobě snoubí zmapování problematiky $\mathrm{z}$ historického hlediska a praktické prrípadové studie. Texty si ponechávají prrístupnou formu a přměřenou míru informační hustoty nerozmělňují $\mathrm{v}$ podružných detailech. Těch může být $\mathrm{v}$ případě potřeby vždy dosaženo dalším studiem, především $z$ adekvátně rozsáhlých přiložených seznamů literatury, pokrývajících jak technickou, tak estetickou stránku věci. Publikaci lze doporučit studentům současné skladby, prríznivcům elektroakustických experimentů či posluchačům soudobé hudební tvorby, ideálně se zájmem o digitální technologie a jejich roli v uměleckém procesu.

Závěrem se vrat'me na počátek: nejproblematičtějším bodem knihy je její název. Otázku role digitálních technologií stranou; její obsah vedle toho prokazatelně operuje s tvorbou nejen pro akustické nástroje. Obě popsaná témata, mnohem zajímavější, než jak je stávající pojmenování avizuje, by si zasloužila název prresnější. Např́klad: Digitálni technologie a algoritmické postupy v hudebni tvorbę?

Jakub Rataj (*1984) je český skladatel zabývající se především př́esahem do elektroakustické tvorby, zvukových instalací či komplexnější prací s lidským tělem a jeho dílčími projevy, jež ve své tvorbě reflektuje.

Gilberto dos Santos Agostinho Filho (*1986) je původem brazilský soudobý skladatel působící př̌edevším v České republice, zaměřující se na počítačovou hudbu a využití algoritmických metod. 